\title{
Caregiver factors and pool fencing: an exploratory analysis
}

\author{
K John Fisher, Kevin P Balanda
}

\begin{abstract}
Objectives-To explore the relationship between caregiver characteristics and the adequacy of domestic swimming pool fencing.
\end{abstract}

Setting-A typical metropolitan area of a large Australian capital city, Brisbane.

Methods-From a reanalysis of the dataset of the 1989 Brisbane Home Safety Survey of 1050 householders, associations between 10 caregiver factors, pool ownership, and quality of pool fencing, were analysed. Household characteristics relating to toddlers (children $\leqslant 4$ years), and socioeconomic measures were also included in the analyses. Pool fencing quality was measured on an ordinal scale derived from Australian Standards Association guidelines, confirmed through home visits by trained inspectors.

Results-Caregiver factors did not distinguish households with a swimming pool from those without, nor were they associated with adequacy of pool fencing among pool owners. Pool owners, with or without children, were less likely to perceive having a childproof fence as being important. Strongest correlates of adequacy of pool fencing were socioeconomic indicators of surrounding districts.

Conclusions-These results do not support the arguments of opponents of compulsory pool fencing that caregiver factors are adequate to prevent toddler drownings and obviate the need for a pool fence. Pool owners do not appear to perceive their pool as a hazard for young children, and complacency about the adequacy of pool fencing needs to be replaced by increased caregiver health beliefs, skills, and perceptions.

(Injury Prevention 1997; 3: 257-261)

Promotion and

Cancer Prevention

Research, Medical

School and

Department of

Movement Studies,

University of

Queensland

K J Fisher

Department of

Human Movement

Studies, University

of Queensland

K P Balanda

Correspondence to: Dr K P Balanda, Centre for Health Promotion and Cancer Prevention

Research, University of Queensland Medical

School, Herston Road,

Herston Q4006, Australia. all childhood drownings in urban areas and $21 \%$ in rural areas.

Many studies have suggested that adequate pool fencing can reduce childhood drownings, with several studies advocating compulsory pool fencing legislation. ${ }^{5-9}$ Almost all toddler drownings in fenced pools occur because the fence is in disrepair or the gate is not functioning. ${ }^{367}$ It is clear that adequate pool fencing and pool safety are essential components of an effective drowning prevention program. ${ }^{378-12}$

The characteristics of the members of the households, their individual and collective knowledge, attitudes and behaviours with respect to pool safety and injury prevention, are often overlooked in physical and environmental audits and safety checklists (J Elkington et al, 1991 unpublished). ${ }^{13}$ Factors that could play a significant part in frequency of child injuries include parents' attentiveness or vigilance, type and consistency of disciplinary actions or instructional behaviours, ${ }^{14}$ as well as parents' beliefs and values. ${ }^{15}$ Several studies have shown levels of supervision to be highly related to the number of hazards in the home ${ }^{16}$ and to childhood injuries. ${ }^{17}$ Caregiver surveillance, attentiveness, and water safety skills take on greater importance in or around water. Taken together, these studies suggest that caregiver characteristics may be strong moderators of the effects of environmental hazards to toddlers such as swimming pools. In fact, opponents of compulsory pool fencing argue that such caregiver factors are adequate to prevent toddler drownings and obviate the need for a pool fence.

The Brisbane Home Safety Survey was conducted, as part of the National Better Health Program, in June $1989 .{ }^{18}$ It was the first in Australia to comprise both a personal interview and a visual assessment of the respondent's household. Households with domestic swimming pools were deliberately oversampled in order to gather detailed information to contribute to an ongoing pool safety campaign. Following the campaign in 1990 , legislation covering pool fencing was introduced in 1991 and was fully implemented in April 1992. The toddler drowning rate fell dramatically from 15 in 1990 to one in 1993, but has now risen to almost prelegislation levels. $^{2}$

In this paper, we undertake a secondary analysis of the 1989 Brisbane Home Safety Survey to explore the potential role of caregiver factors such as: pool safety knowledge, attitudes and beliefs, perceived importance of pool fencing, parent/caregiver surveillance and attentiveness, perceptions of toddler's abilities, and caregiver resuscitation skills, in the prevention of toddler pool drownings. 
In particular, we focus on differences between pool owners and non-pool owners, and on the relationship between caregiver factors and the quality of the pool fence among pool owners. In this way we hope to shed light on whether or not these caregiver factors explain some of the variation in adequacy of domestic pool fencing in the households in the Brisbane Statistical Division.

\section{Methods}

\section{BRISBANE HOME SAFETY SURVEY}

The Brisbane Home Safety Survey was conducted in June 1989. Details of survey methodology are given elsewhere. ${ }^{6} 1819$ Personal interviews of residents in randomly selected Brisbane households were conducted by trained female interviewers. After each interview the interior and exterior of the respondent's household was assessed and the results recorded on a 'household checklist'. An independent market research company undertook the fieldwork following the delivery of an explanatory leaflet to households and promotion of a telephone 'hot line' at Queensland Health, the State Health Department. Six households were chosen from each of 165 randomly selected Australian Bureau of Statistics collectors districts (street blocks) in the Brisbane Statistical Division. Interviewers returned to a household twice, before moving to the next available address in a collectors district. Quotas of at least 200 households with swimming pools and 200 households with an occupant aged 65 years or over were imposed. The quota on households with older residents was filled without oversampling. However, to fill the swimming pool quota an additional 47 households with swimming pools were sought after interviews in households with older residents ceased. Weighting used to adjust for this oversampling was based on the pool prevalence observed before the oversampling began.

During the initial fieldwork, 1399 persons were eligible for interview. Of these, 18.9\% refused to be interviewed, and a further $9.4 \%$ who agreed to be interviewed at a later time were replaced (as outlined above) before the could be done. This resulted in 1003 inter views with an overall participation rate of $71.7 \%$. Fieldwork then continued until further 47 households with swimming pooß were included, resulting in a total of $105 \vec{\theta}$ interviews.

The personal interview covered a range of pool safety issues, including support for compulsory fencing of all domestic swimming pools, methods used to prevent drownings, and perceptions about the swimming skills of children. In addition, general demographic and household information was collected. The household checklist recorded the type of swimming pool, the configuration of any pog fence, and pool fence characteristics, such height, distance between horizontal and verti. cal elements, and the presence of a self closing gate and a child resistant lock. Further details of the items relating to pool safety are give elsewhere. ${ }^{19}$

\section{CAREGIVER FACTORS}

The term young child or toddler, refers to a chilg aged 4 years and younger. As well as demographic details, the questionnaire assessed 10 caregiver factors grouped into beliefs, behas viours, and skills. Definitions are given in the Appendix.

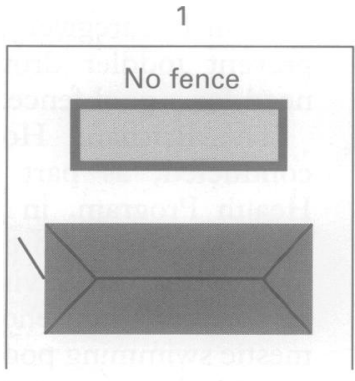

Open street access

4

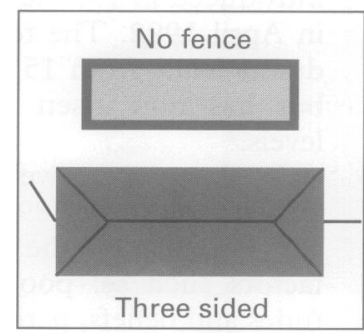

Three sided house access
2

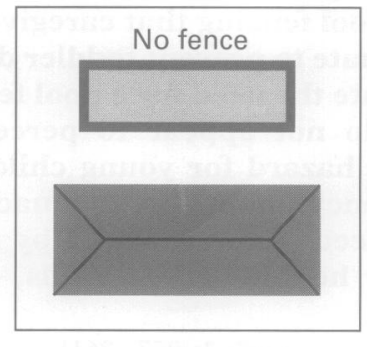

Fenced boundary

5

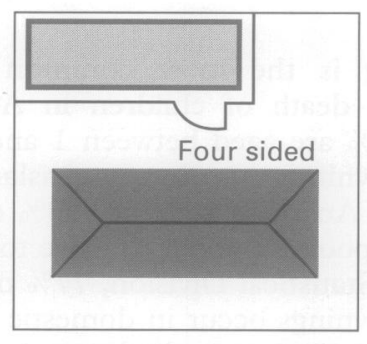

Four sided isolation

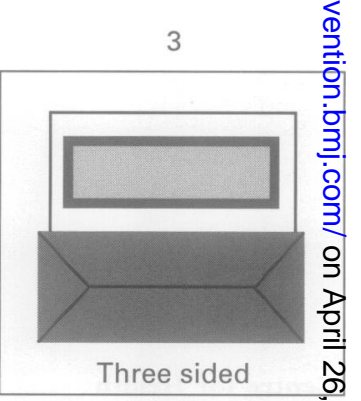

Three sided house acces?
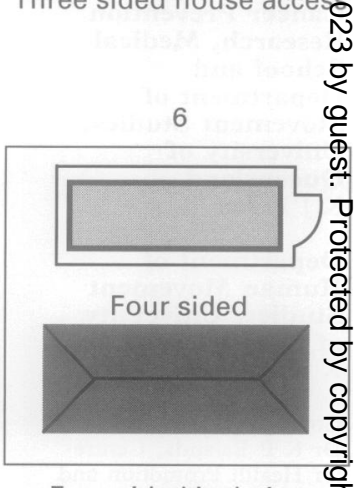

Four sided isolation

7: No fencing at all (no fence) 
HOUSEHOLD CHARACTERISTICS

In addition, two further household characteristics were recorded: the number of children aged 4 years or under, and (in households without children) whether or not they had been visited by a child aged 6 years or under in the last six months.

\section{SOCIOECONOMIC INDICATORS}

Finally, two area based socioeconomic indicators were obtained from the Australian Bureau of Statistics. These were based on census data for the street blocks surrounding each household and reflect the level of economic resources of the district and the education occupation profile of its residents.

\section{POOL FENCE CHARACTERISTICS}

As well as pool ownership (ascertained by visual inspection of the garden), the adequacy of pool fencing was measured on a three point ordinal scale describing the configuration of the fence (see figure). Trained female interviewers visually assessed the pool fence and recorded its configuration in relation to the eight diagrams derived from Australian Standards Association guidelines in operation at the time. ${ }^{11}$ These were collapsed to form an ordinal scale with three levels: unfenced (diagrams 7, 1, and 2), three sided (diagrams 3 and 4 ), and four sided (diagrams 5 and 6 ). In a

Table 1 Demographic characteristics of householders by pool ownership ( $n=1050$ ); values are per cent unless otherwise indicated

\begin{tabular}{lcccc}
\hline Demographic characteristics & Total & Pool owner & Non-pool owner & $p$ Value \\
\hline Sex: male & 23.7 & 25.2 & 17.7 & 0.022 \\
Age (years) & 29.3 & 27.5 & 29.8 & $<0.001$ \\
$\quad \leqslant 34$ & 39.2 & 65.1 & 33.9 & \\
$35-54$ & 31.5 & 7.4 & 36.3 & $<0.001$ \\
$55+$ & 77.7 & 74.0 & 92.6 & 0.002 \\
Owns house/buying & 17.5 & 9.8 & 19.6 & \\
Education & 53.2 & 50.5 & 53.9 & \\
$\quad$ Presecondary & 29.3 & 39.7 & 26.5 & $<0.001$ \\
Some secondary & 46.7 & 71.1 & 40.5 & 0.0001 \\
$\quad$ Some postsecondary & 1008.17 & 1030.44 & 1002.46 & 0.0001 \\
Income of > $\$ 30$ 000 & 1030.71 & 1076.93 & 1019.36 & \\
Education and occupation & &
\end{tabular}

* Socioeconomic indicator for area score representing education and occupation profile of the district.

† Socioeconomic indicator for area score representing economic resources of the district.

$\ddagger$ Mean scores reported and compared. case-referent study conducted in 1991, Pitt and Balanda found this description of pool fencing to be associated with the risk of immersion involving unintended access. ${ }^{6}$ The characteristics of the pool fences in the sample are described elsewhere. ${ }^{19}$

\section{STATISTICAL METHODS}

To facilitate analyses, demographic characteristics and caregiver factors were dichotomised. Standard bivariate statistical procedures were then used to assess differences between the demographic characteristics of pool owners and non-pool owners. The $\chi^{2}$ test was then used to assess crude differences in the caregiver factors of pool owners and non-pool owners.

Logistic regression was then used to adjust $p$ values for demographic differences between pool owners and non-pool owners (see table 2).

Ordinal regresssion was used to calculate both crude and adjusted $p$ values measuring the strength of the relationship, among pool owners, between the caregiver factors and the quality of the pool fence. Covariates included in the adjustment were the same as those above.

\section{Results}

Crude comparisons of characteristics of household respondents show that respondents with pools were more likely to be males, to be younger, and to have some postsecondary education. Moreover, they had significantly higher incomes and lived in areas that had higher mean education and occupation scores, and higher economic resources scores (see table 1). It was noted that more non-pool owners either owned their own house or were in the process of buying one. Over one quarter of pool owners in our sample were not owner/ buyers of their homes.

Table 2 shows the differences in the caregiver factors of respondents with pools and those without pools. Crude $\mathrm{p}$ values are adjusted for demographic differences identified in table 1. Perceived importance of having a childproof fence was the only caregiver factor that distinguished pool owners and non-pool owners in this sample, $(p<0.001$; adjusted $\mathrm{p}=0.006$ ), with non-pool owners considering

Table 2 Caregiver factors of household respondents, by pool ownership ( $n=1050)$; values are per cent unless otherwise indicated

\begin{tabular}{|c|c|c|c|c|c|}
\hline Caregiver factors & Total & $\begin{array}{l}\text { Pool } \\
\text { owner }\end{array}$ & $\begin{array}{l}\text { Non-pool } \\
\text { ouner }\end{array}$ & $\begin{array}{l}\text { Crude } \\
p \text { value }\end{array}$ & $\begin{array}{l}\text { Adjusted } \\
p \text { value }\end{array}$ \\
\hline $\begin{array}{l}\text { All householders } \\
\text { High perceived importance } \\
\text { High perceived behavioural control* } \\
\text { High perceived susceptibility } \\
\text { CPR training } \\
\text { Young children } \\
\text { Householders with young children } \\
\text { Perceived bath skills } \\
\text { Perceived general skills } \\
\text { Households without young children } \\
\text { Recent visit by small children }\end{array}$ & $\begin{array}{l}n=1050 \\
91.6 \\
3.66 \\
13.4 \\
16.0 \\
21.0 \\
n=220 \\
11.10 \\
13.36 \\
\text { n=880 } \\
56.5\end{array}$ & $\begin{array}{l}n=207 \\
78.3 \\
3.64 \\
11.6 \\
19.8 \\
21.3 \\
n=44 \\
12.16 \\
15.22 \\
n=90 \\
62.2\end{array}$ & $\begin{array}{l}n=843 \\
94.9 \\
3.66 \\
13.9 \\
15.1 \\
20.9 \\
n=176 \\
10.83 \\
12.89 \\
n=790 \\
55.6\end{array}$ & $\begin{array}{r}<0.001 \\
0.732 \\
0.388 \\
0.095 \\
0.905\end{array}$ & $\begin{array}{l}0.006 \\
0.689 \\
0.675 \\
0.255 \\
0.997 \\
0.440 \\
0.067 \\
0.8635\end{array}$ \\
\hline
\end{tabular}

* Mean scores reported and compared (see table 1).

$\mathrm{CPR}=$ cardiopulmonary resuscitation. 
Table 3 Adequacy of pool fencing by caregiver factors among households with swimming pools ( $n=207)$; values are per cent unless otherwise indicated

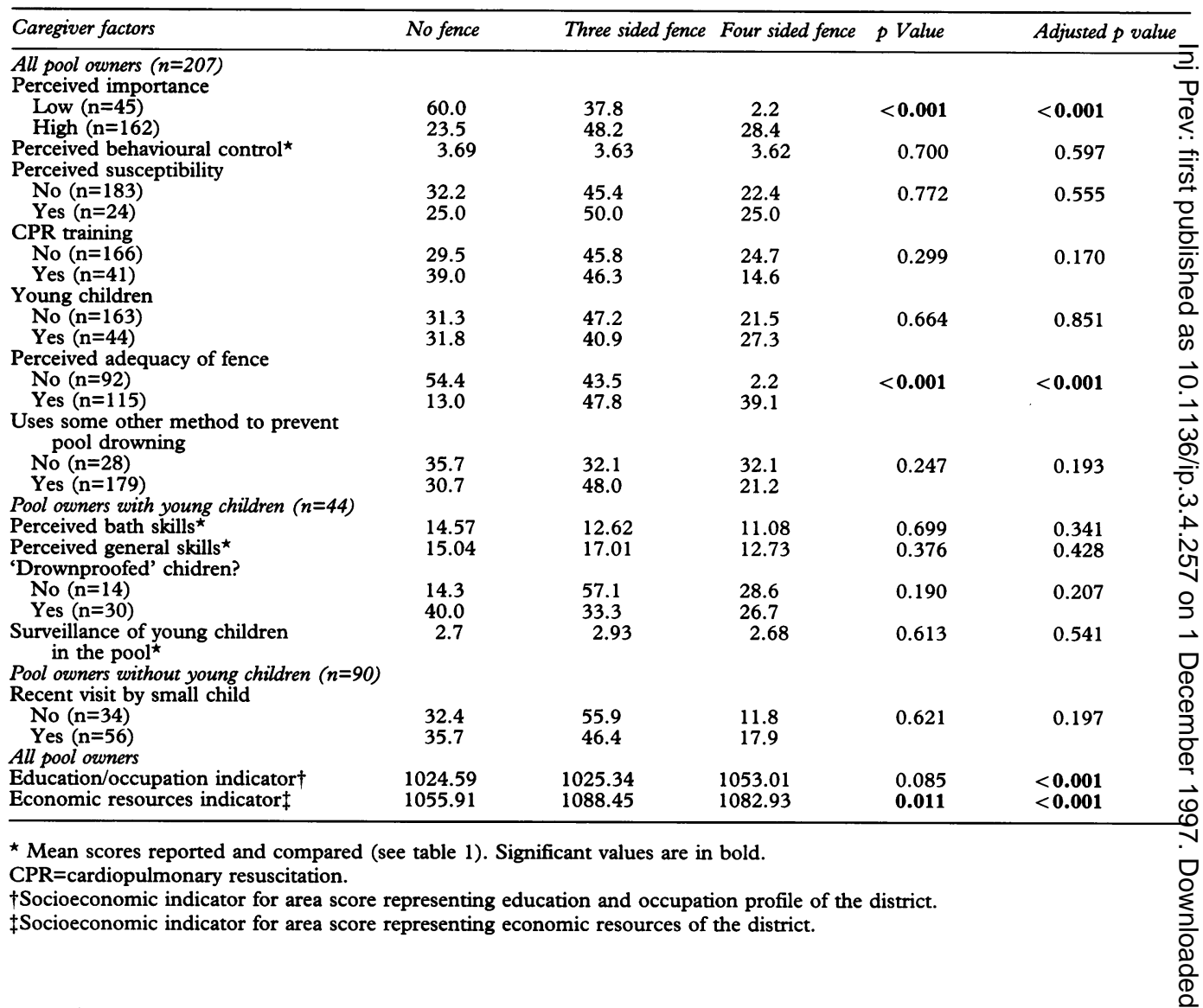

pool fencing significantly more important than pool owners. Moreover, after adjustment for differences in the demographic profiles of pool owner and non-pool owners, this remained statistically significant.

The quality of pool fencing among our subsample of 207 pool owners was measured as a trichotomous variable according to three types of fencing configurations, as mentioned above.

Assessment of the effects of caregiver factors on the adequacy of pool fencing are given in table 3. They indicate that only perceived importance of having a childproof fence $(p<0.001)$, perceived adequacy of the pool fence $(p<0.001)$, and the two socioeconomic status measures (education and occupation $(p=0.085)$ and economic resources of the district $(p=0.011)$ ) were significantly associated with more adequate pool fencing. These associations were strengthened when adjusted for demographic differences between householders.

\section{Discussion}

We have reported an exploratory analysis of a data set that was not designed for this purpose. Consequently, in some cases, small sample sizes (for example pool owners with toddlers, $\mathrm{n}=44$ ) considerably limit statistical power. In addition, key questions were often only asked of a participatory subgroup of respondents to minimise respondent burden.

Nevertheless, the study has identified some issues that are relevant to the current debate regarding compulsory pool fencing. Caregiver factors did not distinguish households with swimming pool from those without. Nor were they associated with the quality of pool fencing among pool owners. Pool owners, in fact, were. less likely to perceive a childproof pool fence as being important. Several explanations are possible. It may be that pool owners compene sate with (i) increased vigilance and contro when children or non-swimmers visit (ii increased cardiopulmonary resuscitation train ing, or (iii) they may feel less susceptible to injury. However, none of these explanations are supported by the study results. Moreoveri no such compensations appeared even wher young children were present in the householdo This is in contrast to the arguments from opponents of compulsory pool fencing thas legislation is not needed as pool safety is being achieved, and can be achieved, through compensatory caregiver factors such as those included in this study.

As these data show, $62 \%$ of households witk a pool were visited by small child (aged 6 years or less) in the last six months. It would seen that pool owners to not perceive their pool to be a hazard for young children, and there may be a role for the health belief model (or simila health behaviour theories) to assist in raising the spectre of the hazard potential of domestie swimming pools among pool owners, whether or not they have children of their own.

The most powerful correlates with the adequacy of a pool fence were the two socioes economic indicators for the surrounding dis? tricts. Adequate pool fencing is relatively expensive and there may be significant financial barriers to the erection of such structures. 
Financial assistance through subsidies may be an important strategy to address the inequitable distribution of adequate pool fencing. Another possible strategy would be to require adequate fencing included in the price of the swimming pool at the point of sale.

A vital issue in the debate about pool fencing adequacy is the question of intended access. Drownings that occur in these circumstances (in many cases, drowning victims are visitors) will not be prevented simply by a fence. An increase in vigilance, surveillance, and subsequently, resuscitation skills by attendant relatives, friends, and visitors may make the difference. Clearly, more research is needed into the complex association between caregiver attitudes and behaviours, social class and equity factors, and multifamily utilisation of a swimming pool such as occurs in higher density housing.

The authors would like to thank Tina Owens and Natalie Paul for their help in the preparation of this manuscript and Dr Ian Ring of Queensland Health for access to the data set of the 1989 Brisbane Home Safety Survey.

1 Kidsafe. The drowning factors. (Summer.) Melbourne: Kidsafe, 1995: 13 .

2 Pitt RW. Toddler pool drowning and pool fencing. OISPP injury bulletin. (Queensland Injury Surveillance and Prevention Project.) December 1995; 34: $1-4$.

3 Nichter $M$, Everett $P$. Childhood near drowning is cardiopulmonary resuscitation always indicated? Crit Care Med 1989; 17: $993-5$.

4 Pitt WR. Increasing incidence of childhood immersion injury in Brisbane. Med $\mathcal{F}$ Aust 1986; 144: 683-5.
5 Pearn J. Safety legislation and child mortality. Med f Aust 1991; 154: 155-6.

6 Pitt W, Balanda $\mathrm{K}$. Childhood drowning and near-drowning in Brisbane: the contribution of domestic swimming pools. Med 7 Aust 1991; 154: 661 - 5 .

7 Miliner N, Pearn J, Guard R. Will fenced pools save lives? Med $\mathcal{F}$ Aust 1980; ii: $510-1$.

8 Pearn J, Nixon J. Are swimming pool becoming more dangerous? Med f Aust 1977; ii: 702-4.

9 Cass D, Ross F, Grattan-Smith T. Child drownings: changing pattern. Med f Aust 1991; 154: 163-5.

10 Lawson J, Oliver T. Domestic pool drowning in children positive results of a practical prevention program. Aust Paediatr ₹ 1978; 14: 275-7.

11 Standards Association of Australia. Guide to swimming pool safety AS 2818-1986. North Sydney, Australia: Standard Association of Australia, 1986.

12 Standards Association of Australia. Fences and Gates for Private Swimming Pools AS 1926-1986. North Sydney, Australia: Standards Association of Australia, 1986.

13 Fisher KJ, Hops H, Davis B, Balanda K, Nixon J, Pitt R Caregiver factors and homehazard assessment: a question of good measure. Proceedings of Third International Conference on Injury Prevention and Control. Melbourne: International Council for Injury Prevention and Control/ National Injury Surveillance Unit (ICIPC/NISU), 1996 $18-22$.

14 Powers TG, Chapieski ML. Childbearing and impulse control in toddlers: a naturalistic investigation. Dev Psychol 1986; 22: $271-5$.

15 Gielen AC, Wilson MEH, Faden RR, Wissow L, Harvilchuck JD. In-house injury prevention for infants and toddlers: the role of parental beliefs, barriers, and housing toddlers: the role of parental beliefs, barriers,

16 Glik DC, Greaves PE, Kronenfeld JJ, Jackson KL. Safety hazards in household with young children. $\mathcal{f}$ Pediat Psychol 1993; 18, 115-31.

17 Harrel WA. The impact of shopping cart restraints and adult supervision on near injuries to children in grocery stores. Accid Anal Prev 1994; 26: $493-500$

18 Balanda KP, Ring IT, Spinks D, Nixon J, Pitt WR Reducing childhood home injuries: the role of local home 20(2): 32-41. Australian fournal of Early Childhood 1991

19 Balanda KP, Spinks D, Ring I, Nixon J, Pitt RW. The Brisbane Home Safety Survey and its role in the Queensland pool safety campaign: domestic swimming pool fencing characteristics, compliance and attitudes. Health Promotion fournal of Australia 1991; 1(2): 37-42.

Appendix Definitions of caregiver factors

\begin{tabular}{|c|c|c|c|}
\hline Caregiver factors & Scope & Basis of measures & Coding \\
\hline $\begin{array}{l}\text { Beliefs } \\
\text { Perceived susceptibility to home } \\
\text { accident }\end{array}$ & All householders & $\begin{array}{l}\text { Self-rating of the chance of an accident occurring in } \\
\text { your household }(1=\text { extremely unlikely to } \\
7=\text { extremely likely) }\end{array}$ & $\begin{array}{l}\text { Susceptible }(\geqslant 5) \\
\text { Not susceptible }(<4)\end{array}$ \\
\hline Importance of childproof pool fencing & All householders & $\begin{array}{l}\text { Direct question ( } 1=\text { very important to } 4=\text { not at all } \\
\text { important, } 5=\text { no opinion) }\end{array}$ & $\begin{array}{l}\text { High }(1) \\
\text { Low }(\geqslant 2)\end{array}$ \\
\hline Perceived behavioural control & All householders & $\begin{array}{l}\text { Response to two statements: 'Most accidents in home } \\
\text { could be prevented' and 'Home safety really a matter } \\
\text { of commonsense' ( } 1=\text { disagree strongly to } \\
5=\text { strongly agree) }\end{array}$ & Mean response \\
\hline Children's general skills & $\begin{array}{l}\text { Householders } \\
\text { with young } \\
\text { children }\end{array}$ & $\begin{array}{l}\text { Responses to age at which a child can 'safely manage stairs', } \\
\text { 'know danger of putting a plastic bag over their head', } \\
\text { and 'play in kitchen without saucepan handles } \\
\text { turned away' }\end{array}$ & 60 minus average age in months \\
\hline Children's bath skills & $\begin{array}{l}\text { Householders } \\
\text { with young } \\
\text { children }\end{array}$ & $\begin{array}{l}\text { 'Age at which a child can have a bath without an adult } \\
\text { being in the bathroom' }\end{array}$ & 60 minus age in months \\
\hline $\begin{array}{l}\text { At least one non-'drownproofed' } \\
\text { child present? }\end{array}$ & $\begin{array}{l}\text { Pool owners } \\
\text { with young } \\
\text { children }\end{array}$ & $\begin{array}{l}\text { 'Which of your children do you think would be able } \\
\text { to regain the side of a pool without assistance if they } \\
\text { fell in?' }\end{array}$ & $\begin{array}{l}\text { Yes (all could) } \\
\text { No (at least one could) }\end{array}$ \\
\hline $\begin{array}{l}\text { Skills } \\
\text { CPR training in last two years }\end{array}$ & All householders & Direct question & $\begin{array}{l}\text { No } \\
\text { Yes }\end{array}$ \\
\hline $\begin{array}{l}\text { Use of at least one method (other } \\
\text { than childproof fencing) to } \\
\text { prevent drowning }\end{array}$ & Pool owners & Direct question (multiple choice) & $\begin{array}{l}\text { Yes } \\
\text { No }\end{array}$ \\
\hline $\begin{array}{l}\text { Behaviours } \\
\text { Surveillance of young children }\end{array}$ & $\begin{array}{l}\text { Pool owners } \\
\text { with young } \\
\text { children }\end{array}$ & $\begin{array}{l}\text { 'How often are your children watched by an adult while } \\
\text { they are swimming in your pool?' ( } 1=\text { never to } 4=\text { at } \\
\text { all times) }\end{array}$ & $\begin{array}{l}\text { Average score for young children who } \\
\text { use the pool }\end{array}$ \\
\hline
\end{tabular}

